\title{
PENGARUH EKSTRAK KAYU MANIS (Cinnamomum sp.) DAN PEMBEKUAN TERHADAP FISIOLOGI IKAN MAS (Cyprinus carpio)
}

\author{
Ruddy Suwandi, Fafa Rizkon Karima, Agoes M Jacoeb, Roni Nugraha* \\ Departemen Teknologi Hasil Perairan, Fakultas Perikanan dan Ilmu Kelautan, IPB University
}

Diterima: 30 Mei 2021/Disetujui: 31 Agustus 2021

Korespondensi: rnugraha@apps.ipb.ac.id

\begin{abstract}
Cara sitasi: Suwandi R, Karima FR, Jacoeb AM, Nugraha R. 2021. Pengaruh ekstrak kayu manis (Cinnamomum sp.) dan pembekuan terhadap fisiologi ikan mas (Cyprinus carpio). Jurnal Pengolahan Hasil Perikanan Indonesia. 24(2): 255-268.
\end{abstract}

\begin{abstract}
Abstrak
Distribusi ikan hidup pascapanen dapat dilakukan dengan perlakuan awal pemingsanan dengan bahan anestesi untuk mengurangi stres selama proses transportasi. Bahan anestesi yang digunakan dapat berupa bahan alami misalnya kayu manis. Penelitian ini bertujuan menentukan pengaruh pemberian larutan ekstrak kulit kayu manis dalam air terhadap waktu pingsan ikan mas, serta menentukan pengaruh lama pemberian pembekuan terhadap laju sintasan, kadar glukosa darah, kondisi mata, dan insang ikan. Konsentrasi terbaik ekstrak kayu manis adalah 1\%, yang menyebabkan ikan pingsan setelah 1,58 $\pm 0,04$ menit. Nilai laju sintasan ikan dengan perlakukan pemingsanan setelah dibekukan mencapai $100 \%$ pada semua waktu pembekuan $-13^{\circ} \mathrm{C}$. Kejutan 45 menit tanpa pemingsanan menghasilkan nilai $100 \%$, sedangkan pada waktu 60 dan 75 menit menghasilkan nilai 88,89\% dan 66,67\%. Insang ikan mas yang diberi pembekuan semakin lama dapat menyebabkan terjadinya pendarahan dan kerusakan pada filamen insang. Waktu pembekuan yang semakin lama membuat nilai glukosa darah semakin meningkat.
\end{abstract}

Kata kunci: Cyprinus caprio, fisiologi ikan, kayu manis, pembekuan, pemingsanan

\section{Effect of Cinnamon (Cinnamomum sp.) Extract and Freezing on the Physiology of Common Carp (Cyprinus carpio)}

\begin{abstract}
Post-harvest live fish distribution can be pretreated with anesthetics to reduce stress levels of the fish. A compound from natural plants such as cinnamon can be used as an anesthetic. This study was aimed to determine the effect of cinnamon extract on the fainting time of common carp, and to determine the effect of freezing shock duration on the survival rate, blood glucose levels, eye, and gill condition. The fish in cinnamon extract $1 \%$ was readily lost of consciousness after $1.58 \pm 0,04$ minutes. The survival rate of stunned fish after freezing reached $100 \%$. Meanwhile, a 45 -minute freezing shock without stunning resulted in the $100 \%$ survival rate, but at 60 and 75 minutes, the survival rate was down to $88.89 \%$ and $66.67 \%$, respectively. The freezing shock caused bleeding and damage to the gill filaments and increased the blood glucose value of the fish.
\end{abstract}

Keywords: cinnamon, Cyprinus caprio, fish physiology, freezing, immotilisation 


\section{PENDAHULUAN}

Ikan mas (Cyprinus carpio) merupakan salah satu ikan air tawar yang memiliki banyak peluang dalam pengembangannya untuk meraih potensi pasar yang terus meningkat. Produksi ikan mas berdasarkan data Kementerian Kelautan dan Perikanan mengalami peningkatan secara berurut dari tahun 2015 hingga 2019 yaitu 461.546, $497.208,320.941,536.349$ dan 584.496 ton (KKP 2020). Selain itu, ikan mas termasuk hewan yang mengandung protein tinggi dan dapat memenuhi gizi masyarakat Indonesia (Syafar et al. 2017). Ikan mas menjadi ikan konsumsi yang banyak digemari oleh masyarakat selain ikan nila dan mujair. Ikan mas menjadi ikan dengan nilai ekonomis tinggi, karena ikan ini memiliki jumlah permintaan yang besar terutama pada beberapa pasar lokal. Ikan mas memiliki daging dengan tekstur yang lembut dengan kandungan gizi yang baik dan memiliki potensi ekonomi yang tinggi serta ikan yang mudah dibudidayakan (Fathihatunnisa 2019). Ikan mas dapat ditemukan di berbagai macam perairan. Ikan mas adalah salah satu jenis ikan air tawar, namun dapat ditemukan juga di perairan payau.

Teknik pemingsanan merupakan salah satu penanganan ikan pascapanen yang banyak digunakan dalam distribusi dari satu tempat ke tempat lainnya. Pemingsanan ikan dapat dilakukan dengan berbagai cara, antara lain dengan arus listrik, suhu rendah dan bahan anestesi. Bahan anestesi pada pemingsanan ikan dapat dibagi menjadi dua jenis yaitu bahan anestesi kimia dan alami. Bahan anestesi kimia yang biasa digunakan antara lain MS222, 2-4 methychinolin (Yanto 2009). Bahan anestesi alami yang dapat digunakan berupa alga laut (Caulerpa racemosa), minyak sereh (Cymbopogon sp.), minyak cengkeh (Syzygium aromaticum), daun jambu (Psidium guajava), ekstrak umbi teki (Cyperus rotundus), dan infusum daun durian (Munandar et al. 2017). Pemingsanan ikan dengan bahan anestesi alami lainnya dapat menggunakan kulit kayu manis (Septiana 2018) dengan konsentrasi esktrak kulit kayu manis 2,5\% dan waktu pingsan 1 menit 47 detik dan waktu bugar 86 detik.
Kayu manis (Cinnamomum sp.) adalah tumbuhan yang banyak ditemukan di Asia Selatan, daratan Cina dan Asia Tenggara. Indonesia merupakan produsen kayu manis terbesar kedua setelah Cina (Prasetyaningrum et al. 2012). Bahan-bahan kimia yang terdapat pada kayu manis yaitu zat penyamak, minyak atsiri, eugenol, damar, kalsium oksalat, tanin, safrol, sinamaldehida (Sari et al. 2016; Puspita 2014). Kandungan eugenol yang ada pada minyak atsiri dapat digunakan sebagai pembius untuk memingsankan ikan (Septiana 2018). Akan tetapi, bahan anestesi tidak mampu membuat ikan pingsan pada waktu yang lama.

Pembekuan diperlukan agar ikan tetap berada dalam kondisi pingsan. Pemberian suhu rendah atau pembekuan dapat menggunakan refrigerasi, es, slurry ice (es cair), air dingin. Ikan yang berada pada suhu rendah atau suhu beku dapat tetap hidup dalam waktu tertentu meskipun daya tahannya ditentukan oleh ukuran ikan tersebut (Rahmahidayati et al. 2014). Suwandi et al. (2020) menyatakan dalam penelitiannya bahwa suhu terbaik untuk membekukan ikan mas yaitu $-13{ }^{\circ} \mathrm{C}$, sehingga ikan mas dapat hidup dan dapat bertahan dalam suhu beku hingga ikan dibugarkan kembali. Pembekuan diduga mampu menjaga ikan tetap hidup dalam kondisi pingsan. Akan tetapi, proses pemingsanan ikan dengan pembekuan secara langsung dapat membuat ikan meronta dan merusak jaringan tubuh. Kombinasi pemingsanan menggunakan bahan anestesi dan pembekuan belum pernah dilakukan pada ikan mas. Oleh karena itu, penelitian ini bertujuan untuk menentukan kondisi ikan yang dipingsankan melalui dua tahap pemingsanan.

\section{BAHAN DAN METODE Bahan dan Alat}

Bahan utama yang digunakan pada penelitian ini adalah ikan mas (dengan bobot rata-rata $100 \mathrm{~g}$ yang diperoleh dari Mandiri Mas Jaya yang terletak di belakang Terminal Laladon, Bogor. Bahan-bahan lain yang digunakan pada penelitian ini yaitu kulit kayu manis. 
Alat-alat yang digunakan pada penelitian ini berupa akuarium dengan ukuran 44x24 x35 $\mathrm{cm}^{3}$, aerator Amara BS410, wadah berukuran $28 \times 20 \times 14 \mathrm{~cm}^{3}$, timbangan digital SF 400 , portable LCD digital microscope user manual(G600), GlukoDR AGM 2100, test strip AGM2100, suntikan, TP 101 termometer digital, freezer AQUA AQV-200 (W), scoresheet, stopwatch, stirofoam, penggaris.

\section{Metode Peneltian \\ Penyiapan ikan dan ekstrak kayu manis}

Pembuatan larutan ekstrak kulit kayu manis dilakukan menurut hasil penelitian Septiana (2018). Pembuatan ekstrak kayu manis dilakukan dengan menghancurkan kulit kayu manis menggunakan ulekan hingga berukuran 3 sampai $5 \mathrm{~cm}$. Kulit kayu manis yang sudah dihancurkan kemudian ditimbang sesuai konsentrasi yang akan dibuat yaitu $1 \%$; $1,5 \%$ dan $2 \%(b / v)$. Selanjutnya, kulit kayu manis diekstraksi dengan cara merebusnya selama 30 menit di dalam $4 \mathrm{~L}$ akuades.

\section{Penentuan konsentrasi ekstrak kayu manis dengan waktu pingsan dan bugar tercepat}

Penentuan pengaruh konsentrasi ekstrak kayu manis terhadap waktu pingsan dan waktu bugar ikan dilakukan menggunakan tiga ekor ikan yang dimasukkan ke dalam $4 \mathrm{~L}$ air ekstrak kulit kayu manis. Pengamatan waktu pingsan ikan dimulai saat ikan dimasukkan ke dalam larutan kayu manis hingga ikan mengalami pingsan. Perhitungan waktu bugar ikan dilakukan saat ikan dipindahkan dari larutan ekstrak kulit kayu manis ke dalam air yang dilengkapi aerator hingga ikan bergerak secara normal.

\section{Pemingsanan ikan dengan ekstrak kayu manis dan pembekuan}

Ikan diaklimatisasi dan dipuasakan terlebih dahulu selama 24 jam, kemudian ikan dipingsankan dengan konsentrasi terpilih. Waktu pingsan dicatat dan tingkah lakunya diamati. Ikan yang sudah pingsan selanjutnya dimasukkan ke dalam freezer dengan suhu $-13{ }^{\circ} \mathrm{C}$ selama 45,60 , dan 75 menit. Suhu -13
${ }^{\circ} \mathrm{C}$ untuk suhu pembekuan ikan mas mengacu pada penelitian Suwandi et al. (2020). Sebelum ikan mas dimasukkan ke dalam freezer, darah ikan diambil menggunakan semprit (syringe) dan kadar glukosanya diukur menggunakan glukometer.

Ikan selanjutnya dibugarkan kembali dengan menggunakan aerasi dan dicatat waktu bugar serta diamati tingkah lakunya. Pembugaran ikan dilakukan di dalam akuarium yang berukuran $44 \times 24 \times 35 \mathrm{~cm}^{3}$. Kadar glukosa darah ikan kembali diukur. Kelangsungan hidup ikan serta perubahan yang terjadi pada mata serta insangnya diamati selama 12 jam. Mata dan insang diamati dua kali, yaitu saat ikan masih dalam keadaan beku dan setelah bugar. Setiap lama waktu pemberian pembekuan dilakukan tiga kali ulangan, dengan masing-masing ulangan menggunakan tiga ekor ikan.

\section{Laju sintasan (survival rate)}

Analisis laju sintasan merupakan analisis data suatu variabel yang diperhatikan yaitu waktu dari awal pengamatan sampai laju sintsan ikan terjadi dengan melihat beberapa variabel yang mampu memengaruhi laju sintasan ikan tersebut. Laju sintasan didapatkan berdasarkan persamaan yang telah dijelaskan oleh Zonneveld et al. (1991):

$\mathrm{SR}=\frac{\mathrm{No}}{\mathrm{Nt}}$

Keterangan:

SR: laju sintasan (\%)

Nt: jumlah ikan pada akhir penelitian (ekor)

No: ikan pada awal penelitian (ekor)

\section{Waktu pingsan dan bugar ikan mas}

Waktu pingsan dan bugar diamati pada ikan dengan pemingsanan dan tanpa pemingsanan. Pencatatan waktu pingsan ikan dengan ekstrak kulit kayu manis dilakukan sejak ikan dimasukkan ke dalam ekstrak kulit kayu manis hingga pingsan. Waktu pingsan ikan tanpa pemingsanan dicatat dari ikan dimasukkan ke dalam freezer hingga pingsan. Waktu pembugaran dicatat sejak ikan dimasukkan ke dalam akuarium hingga sadar sepenuhnya. 


\section{Pengamatan mata dan insang}

Kondisi mata dan insang ikan diamati menggunakan alat mikroskop digital user manual-(G600). Mata ikan diamati pada kondisi beku dan bugar namun insang diamati saat kondisi ikan sudah bugar.

\section{Analisis kadar glukosa darah (GlucoDR AGM 2100) (Roohi dan Imanpoor 2015)}

Analisis glukosa darah diuji menggunakan alat GlucoDR AGM 2100. Penggunaan alat ini dilakukan dengan memasukan test strip ke dalam port test. Darah yang akan diuji ditempelkan pada test strip dengan jumlah minimal darah $4 \mu \mathrm{L}$ dalam satu kali pengujian. Hasil pengujian dapat dilihat pada layar alat GlucoDR AGM 2100 dan kadar glukosa darah yang dihasilkan memiliki nilai rentang 30-600 $\mathrm{mg} / \mathrm{dL}$.

\section{Rancangan percobaan dan analisis data}

Data hasil pengujian yang didapat diolah dengan menggunakan perangkat lunak Microsoft Excel 2007 dan Statistical Product and ServiceSolutions (SPSS) 21, serta disajikan dalam bentuk grafik. Pengaruh konsentrasi ekstrak kayu manis terhadap waktu pingsan dan waktu bugar dianalisis dengan metode rancangan acak lengkap (RAL) satu faktor. Perlakuan untuk RAL satu faktor berupa yaitu $1 \% ; 1,5 \%$ dan $2 \%(\mathrm{~b} / \mathrm{v})$.

\section{HASIL DAN PEMBAHASAN Konsentrasi Terpilih Ekstrak Kayu Manis untuk Pemingsanan}

Penentuan konsentrasi terpilih ekstrak kayu manis mengunakan tiga konsentrasi yaitu $1 \%, 1,5 \%$ dan $2 \%$. Konsentrasi ditentukan dengan melihat waktu pingsan dan waktu bugar ikan. Hasil penentuan konsentrasi terbaik kulit kayu manis dapat dilihat pada Figure 1.

Figure 1 menunjukkan bahwa semakin besar konsentrasi ekstrak kayu manis yang digunakan untuk memingsankan ikan, maka waktu pingsannya akan semakin cepat dan waktu bugarnya pun akan semakin lama. Hasil tersebut sesuai dengan penelitian Arlanda et al. (2018), bahwa semakin tinggi konsentrasi yang digunakan untuk pemingsanan ikan, maka semakin banyak juga kandungan ekstrak ataupun senyawa aktif yang terserap ke dalam tubuh ikan, sehingga ikan akan semakin cepat mengalami pingsan dan semakin lama juga waktu yang dibutuhkan ikan untuk bugar. Konsentrasi ekstrak kayu manis yang berbeda memengaruhi secara nyata waktu pingsan dan waktu bugar ikan mas $(p<0,05)$. Konsentrasi terbaik pemingsanan ikan menggunakan ekstrak kulit kayu manis yang didapatkan yaitu konsentrasi $1 \%$ dengan waktu pingsan dan waktu bugar yang lebih cepat dibandingkan dengan konsentrasi $1,5 \%$ dan $2 \%(p<0,05)$. Waktu pingsan dan waktu bugar yang diperoleh yaitu $1,58 \pm 0,04$

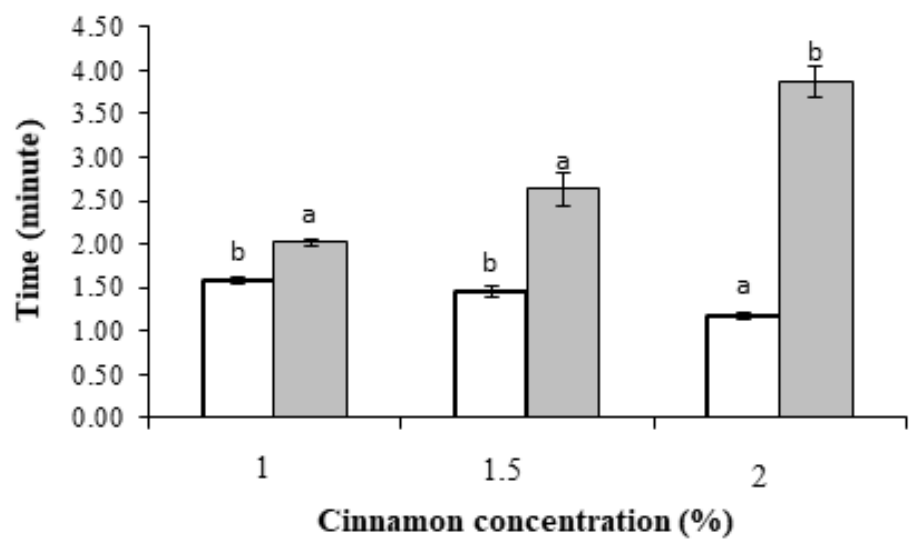

Figure 1 Effects of cinnamon concentration on the induction time (empty bar) and the recovery time (shaded bar) of the carp. Different letters on the bar indicate significant differences $(p<0.05)$. 
menit pada waktu pingsan dan 2,20 $\pm 0,04$ menit pada waktu bugar. Bahan anestesi dinyatakan efektif untuk memingsankan ikan yaitu yang memiliki waktu pingsan kurang dari 3 menit. Selain itu, bahan anestesi yang baik dapat membuat ikan bugar kurang dari 5 menit (Aini et al. 2014). Proses pemingsanan membuat ikan mengalami perubahan tingkah laku.

Ikan mas yang diberi ekstrak kulit kayu manis saat pemingsanan terjadi perubahan tingkah laku, yaitu ikan mengalami penurunan pergerakantubuh,operkulumbergeraklambat, badan tidak seimbang, metabolisme menurun dan tidak memiliki reaksi pada rangsangan luar. Hal ini sesuai dengan pernyataan Arlanda et al. (2018), bahwa ikan yang mengalami fase pingsan memiliki pergerakan renang yang pasif, sistem kerja metabolisme dan respirasi mengalami penurunan, pergerakan operkulum mengalami penurunan serta ikan tidak mempunyai reaktivitas terhadap rangsangan dari luar kecuali berupa suatu tekanan yang cukup besar. Efektivitas ikan bugar memiliki waktu kurang dari 5 menit. Ikan pingsan yang dilakukan penyadaran akan diawali dengan pergerakan operkulum, badan ikan secara perlahan akan bergerak dan mengeluarkan ekstrak yang terdapat di dalam tubuh ikan hingga bugar sepenuhnya. Hasil tersebut sesuai dengan pernyataan Khalil et al. (2013), bahwa ikan yang mulai sadar ditandai dengan pergerakan operkulumnya, beberapa saat setelahnya ikan akan berenang dengan perlahan hingga kembali bugar. Semakin tinggi konsentrasi yang diberikan membuat ikan semakin lama juga untuk sadar karena semakin tinggi konsentrasi maka semakin banyak pula kandungan ekstrak yang terserap. Aini et al. (2014) menyatakan bahwa bahan anestesi yang efektif digunakan untuk memingsankan ikan yaitu memiliki waktu pingsan kurang dari 3 menit dan dapat membuat ikan bugar kurang dari 5 menit. Ikan yang pingsan lebih dari 3 menit akan mengalami stres secara berlebih sehingga dapat menyebabkan ikan mengalami kematian. Selain itu, penentuan konsentrasi terbaik dengan melihat jumlah konsentrasi yang digunakan. Konsentrasi yang digunakan semakin banyak maka membuat waktu pingsan ikan akan semakin cepat dan waktu bugarnya akan semakin lama. Semakin besar konsentrasi yang digunakan untuk memingsankan ikan juga dapat berakibat fatal yaitu mampu membuat ikan mengalami kematian. Ikan yang dipingsankan dengan konsentrasi yang semakin besar maka kandungan toksisitas yang masuk ke dalam tubuh ikan pun akan semakin besar sehingga dapat menyebabkan kematian. Maryani et al. (2018) menyatakan bahwa konsentrasi yang semakin besar membuat bahan aktif untuk memingsankan ikan pun akan semakin toksik sehingga mampu memberikan respon kematian pada ikan yang semakin besar juga.

\section{Perubahan Tingkah Laku Ikan Mas}

Pemingsanan ikan merupakan salah satu teknik penanganan yang dapat dilakukan agar ikan tidak mengalami stres selama pengangkutan dan mengurangi berat beban pengangkutan ikan (Maraja et al. 2017). Pemingsanan ikan dilakukan menggunakan ekstrak kulit kayu manis 1\% dan pembekuan $-13{ }^{\circ} \mathrm{C}$. Pengamatan pemingsanan ikan menggunakan ektrak kulit kayu manis dimulai saat ikan dimasukkan ke dalam larutan ekstrak, sedangkan pengamatan pemingsanan menggunakan suhu rendah $-13{ }^{\circ} \mathrm{C}$ saat ikan dimasukkan ke dalam freezer. Ikan yang dipingsankan menggunakan ekstrak kulit kayu manis $1 \%$ pada detik ke 0-30 masih dalam keadaan normal, yakni badan berdiri tegak, operkulum dan mulut bergerak normal. Tingkah laku ikan pada detik 30-60 mulai panik ditandai dengan ikan mulai menggelepar. Detik ke 60-90 ikan kehilangan kendali dan ikan bergerak pasif. Kondisi ikan pada detik ke 90-120 badan miring, posisi berada di dasar, operkulum dan mulut bergerak lambat serta reaktivitas terhadap rangsangan dari luar hingga ikan mengalami pingsan.

Ikan yang dipingsankan dengan suhu rendah $-13{ }^{\circ} \mathrm{C}$ mengalami kepanikan pada menit 1-3 ditandai dengan operkulum mulut bergerak cepat. Pada menit 3-5 badan mulai diam, operkulum dan mulut bergerak cepat serta masih memiliki reaktivitas terhadap rangsangan dari luar yang sangat kecil. Keadaan ikan saat menit ke 5-6 badan 
diam, operkulum dan mulut bergerak lambat, serta ikan tidak memiliki reaktivitas terhadap rangsangan dari luar walaupun sangat kecil hingga ikan pingsan. Hasil yang didapat pada penelitian ini sesuai dengan pernyataan Arlanda et al. (2018), bahwa ikan dalam fase pingsan ditandai dengan terjadinya pergerakan operkulum mengalami penurunan, penurunan sistem kerja metabolisme dan repirasi, serta ikan tidak mempunyai reaktivitas terhadap rangsangan dari luar kecuali berupa suatu tekanan yang cukup besar.

\section{Waktu Pingsan Ikan Mas}

Pemingsanan ikan menggunakan ekstrak kayu manis dan pembekuan dilakukan untuk mempersingkat waktu pemingsanan dan mengurangi tingkat stres ikan. Pemingsanan ikan dengan suhu rendah merupakan pemingsanan yang aman digunakan, sebab pemingsanan dengan cara ini tidak akan meninggalkan residu kimia di dalam ikan yang dipingsankan (Maraja et al. 2017). Waktu pemingsanan ikan mas menggunakan ekstrak kulit kayu manis $1 \%$ dan tanpa ekstrak kayu manis 1\% dapat dilihat pada Figure 2.

Figure 2 menunjukkan waktu pingsan dengan menggunakan ekstrak kayu manis $1 \%$ memperoleh hasil yang tidak berbeda jauh yaitu memiliki kisaran waktu selama 1-2 menit, sedangkan waktu pingsan ikan tanpa menggunakan ekstrak kayu manis $1 \%$ memiliki kisaran waktu selama 5-6 menit. Kondisi ini sesuai dengan pengamatan Aini et al. (2014) yang menggunakan bahan anestesi dengan waktu pingsan kurang dari 3 menit dapat dikatakan sebagai bahan anestesi yang sangat efektif untuk memingsankan ikan. Ekstrak kulit kayu manis dapat digunakan sebagai bahan anestesi karena mengandung minyak atsiri yang terdiri dari kamfer, safrol, eugenol, sinamaldehida, sinamilasetat, terpen, sineol, sitral, sitronelal, polifenol dan benzaldehida. Selain itu kulit kayu manis meemiliki kandungan lain di antaranya alkaloid, flavonoid, dan tanin(Anto dan Rato 2018).

Minyak atsiri di dalam kayu manis mempunyai suatu senyawa yang sangat penting untuk memingsankan ikan, salah satunya yaitu eugenol. Eugenol sendiri masuk ke dalam golongan zat cair, yang dapat larut dalam pelarut, misal air, kloroform dan alkohol (Septiana 2018). Kandungan senyawa eugenol yang terdapat di dalam kulit kayu manis 17,62\% (Djarot et al. 2019). Senyawa dapat digunakan sebagai bahan anestesi karena senyawa ini dapat memberikan efek halusinasi pada ikan hingga menyebabkan ikan pingsan. Efek halusinasi diakibatkan karena senyawa eugenol ini masuk ke dalam golongan senyawa alkaloid yang mampu menyebabkan ikan mengalami pingsan jika senyawa ini masuk ke dalamnya dengan konsentrasi yang sesuai (Nur'aini 2016).

Hasil yang diperoleh waktu pemingsanan tanpa ekstrak kayu manis $1 \%$ membutuhkan waktu pingsan yang lama. Hal tersebut berbeda dengan penelitian Pratisari (2010) yang memingsankan ikan nila (Oreochromis niloticus) dengan suhu rendah secara langsung

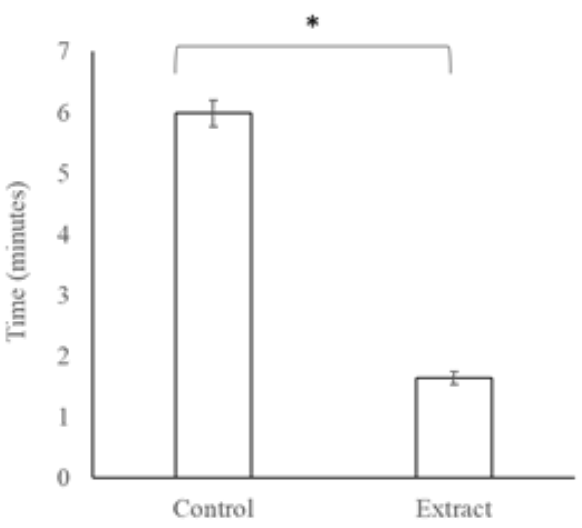

Figure 2 Induction time of carp at freezing temperature $\left(-13^{\circ} \mathrm{C}\right)$ with addition of cinnamon extract. Note: ${ }^{\star}$ significantly different from control $(p<0.05)$. 
menggunakan es sebanyak $2 \mathrm{~kg} / 1 \mathrm{~L}$ air pada suhu $6-7^{\circ} \mathrm{C}$ mendapatkan waktu pingsan ikan selama 10 menit. Hasil tersebut juga berbeda dengan penelitian Arsyad et al. (2014) yang mendapatkan waktu pingsan ikan lele (Clarias sp.) dan gurami (Osphronemus goramy) dengan suhu rendah $8{ }^{\circ} \mathrm{C}$ secara bertahap yaitu 3,36 menit dan 4,51 menit. Perbedaan disebabkan karena ikan mas merupakan ikan termofili sehingga lebih kuat dan mampu menyesuaikan diri terhadap perubahan serta kondisi lingkungan yang ekstrim (Arsyad et al. 2014).

Hal ini sesuai dengan penelitian Primadona et al. (2017) bahwa ikan yang dipingsankan dengan suhu rendah membutuhkan waktu yang cukup lama. Waktu yang dibutuhkan untuk memingsankan ikan dengan suhu rendah bahkan bisa mencapai 20-45 menit tergantung jenis dan ukuran ikannya. Semakin besar ukuran ikan yang digunakan maka akan semakin lama juga waktu yang dibutuhkan untuk memingsankan ikan (Arsyad et al. 2014).

Ikan yang dipingsankan dengan cara ini ketika dimasukkan ke dalam freezer bersuhu $-13{ }^{\circ} \mathrm{C}$ mengalami kepanikan ditandai dengan ikan menggelepar-gelepar, bergerak tidak beraturan dan pergerakan mulut serta operkulum yang begitu cepat. Hal tersebut didukung oleh Suwetja et al. (2016) yang menyatakan ikan yang dimasukan ke dalam suhu rendah akan mengalami kepanikan, hal ini disebabkan perubahan suhu yang terjadi secara tiba-tiba sehingga membuat ikan kaget dan panik. Ikan yang panik akan menggelepar tetapi secara perlahan operkulum dan mulut ikan mulai bergerak lambat namun membutuhkan waktu yang lama untuk pingsan. Ikan yang mengalami kepanikan karena pemberian suhu rendah dapat membuat ikan mengalami stres bahkan dapat menyebabkan kematian. Hal tersebut sesuai dengan yang dijelaskan dalam penelitian Nuraini (2016) bahwa ikan yang diberi suhu rendah dapat mengalami stres bahkan menyebabkan kematian, karena suhu rendah merupakan sumber stres yang berpengaruh terhadap perubahan fisiologis yang terjadi pada tubuh ikan dan suhu yang tidak sesuai dengan suhu lingkungan tempat ikan hidup dapat membuat ikan mengalami kematian.

\section{Laju Sintasan Ikan Mas dengan Pemingsanan dan Tanpa Pemingsanan}

Laju sintasan ikan dapat dipengaruhi oleh adanya perlakuan. Hal tersebut terbukti dengan adanya perbedaan pada laju sintasan ikan dengan pemberian pembekuan yang berbeda baik ikan yang dipingsankan maupun ikan yang tidak dipingsankan. Perbedaan waktu pembekuan yang diberikan yaitu 45 , 60, dan 75 menit. Hasil tersebut dapat dilihat pada Figure 3.

Figure 3 menunjukkan adanya perbedaan pada nilai laju sintasan ikan mas. Semakin lama waktu kejutan suhu yang diberikan maka akan semakin memengaruhi kelangsungan hidup ikan. Pembekuan 45 menit memperoleh nilai laju sintasan $100 \%$ baik yang dipingsankan

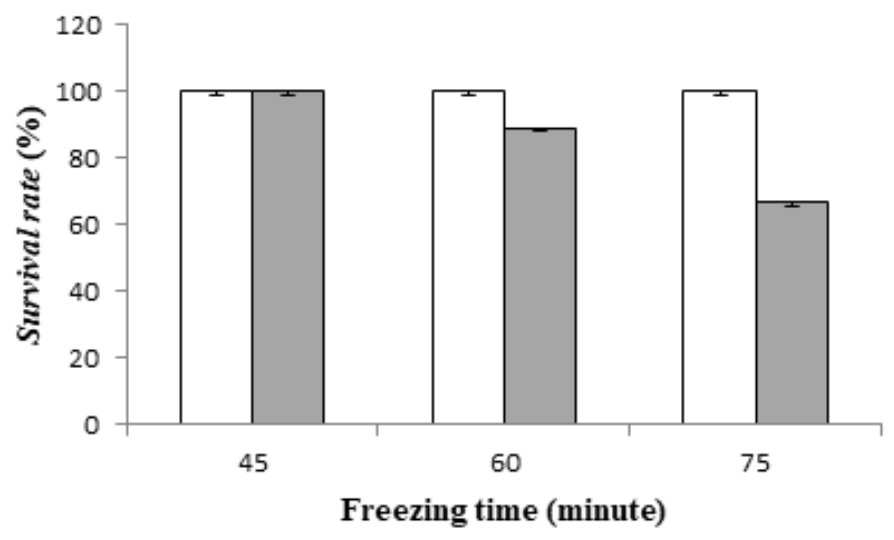

Figure 3 Survival rate of the carp stunted at $-13^{\circ} \mathrm{C}$ with (white bar) and without (grey bar) prior addition of cinnamon extract. 
maupun yang tidak dipingsankan. Nilai laju sintasan ikan mas pada pembekuan 60 dan 75 dengan pemingsanan adalah $100 \%$ sedangkan ikan yang tidak dipingsankan pada waktu pembekuan 60 memperoleh nilai $88,89 \%$ dan $66,67 \%$ pada pembekuan 75 menit. Hasil yang didapat dengan pemingsanan menggunakan ekstrak kayu manis memiliki nilai laju sintasan yang lebih baik dibandingkan dengan ikan yang tidak diberikan pemingsanan terlebih dahulu, hal ini dapat disebabkan bahwa ikan yang dipingsankan menggunakan ekstrak kayu manis dapat menurunkan tingkat metabolisme ikan sehingga tingkat stres ikan akan ikut terhambat. Hal tersebut sesuai dengan penelitian Yustiati et al. (2017) yang mendapatkan hasil nilai laju sintasan ikan nila menggunakan pemingsanan lebih tinggi dibandingkan ikan yang tanpa pemingsanan. Hasil tersebut juga sesuai dengan penelitian yang dilakukan Heriyati dan Kasman (2017) yang menggunakan ikan kerapu macan (Epinephelus fuscoguttatus) dengan perlakuan pemingsanan suhu rendah $15^{\circ} \mathrm{C}$ dan perbedaan lama waktu transportasi ikan menunjukan bahwa semakin lama waktu transportasi yang diberikan maka ikan akan mengalami kematian. Ikan yang dipingsankan terlebih dahulu dapat menekan tingkat stres ikan yang dapat menyebabkan kematian (Yustiati et al. 2017). Laju sintasan ikan dapat dipengaruhi oleh suhu karena ikan dikhawatirkan tidak mampu hidup dalam kondisi di luar habitatnya (Heriyati dan Kasman 2017).

Ikan dengan pemingsanan dan pembekuan diduga dapat mencegah peningkatan stres pada ikan. Ikan tanpa pemingsanan mengalami stres yang berlebih disebabkan adanya perubahan suhu secara tiba-tiba yang membuat ikan mengalami kepanikan. Hal tersebut sesuai dengan penelitian Nugraha (2019) bahwa ikan dengan perlakuan pembekuan yang semakin lama dapat membuat ikan tidak dapat bertahan dan menyebabkan kematian. Ikan yang diberi pemingsanan terlebih dahulu memperoleh nilai $100 \%$ disebabkan adanya zat anestesi yang mampu mencegah ikan mengalami stres berlebih. Hal tersebut didukung dengan pernyataan Fathihatunnisa (2019), bahwa ikan yang diberi perlakuan pemingsanan terlebih dahulu dapat membuat tingkat metabolisme ikan menjadi rendah, sehingga peningkatan stres ikan akan terhambat dan mencegah kematian pada ikan. Ikan yang mengalami stres tinggi kemungkinan akan mati karena ikan pada kondisi ini akan banyak menggunakan energi, sehingga homeostasis di dalam tubuh ikan akan terganggu, yang berakibat pada kematian. Ikan yang tidak dipingsankan metabolismenya akan terus meningkat, yang disebabkan oleh stres karena adanya perubahan suhu secara tiba-tiba dan tidak sesuai dengan suhu lingkungan hidup ikan (Nur'aini 2016). Selain itu, pembekuan dapat meningkatkan aktivitas metabolisme yang membuat ikan membutuhkan banyak oksigen, namun oksigen yang ada di dalam tempat penyimpanan ikan sangat terbatas membuat ikan mengalami kekurangan oksigen yang berujung pada kematian (Suwetja et al. 2016).

\section{Kondisi Ikan Mas Selama 12 Jam}

Ikan yang sudah dibugarkan perlu diamati selama 12 jam. Pengamatan ikan selama 12 jam bertujuan untuk menentukan daya tahan ikan setelah diberi perlakuan pembekuan yang berbeda yaitu 45, 60 dan 75 menit baik dengan pemingsanan maupun tidak menggunakan pemingsanan. Pengamatan kondisi ikan selama 12 jam dilihat secara visual dengan melihat jumlah ikan yang mati setiap jamnya. Kelangsungan hidup ikan selama 12 jam dapat dilihat pada Figure 4.

Figure 4 menunjukkan terjadinya penurunan kondisi ikan selama 12 jam. Perubahan nilai laju sintasan dengan pemingsanan terjadi pada jam ke-6 untuk yang dibekukan selama 75 menit, jam ke- 9 yang dibekukan 60 menit, jam ke-1 untuk yang dibekukan selama 60 dan 75 menit tanpa pemingsanan, sedangkan yang dibekukan 45 menit tidak ada perubahan nilai laju sintasan baik menggunakan pemingsanan maupun tanpa pemingsanan. Hal ini disebabkan adanya perbedaan waktu pembekuan yang memengaruhi kelangsungan hidup ikan selama 12 jam. Ikan yang diberi pembekuan semakin lama akan membuat kondisinya selama 12 jam menurun. Selain itu, pemberian 


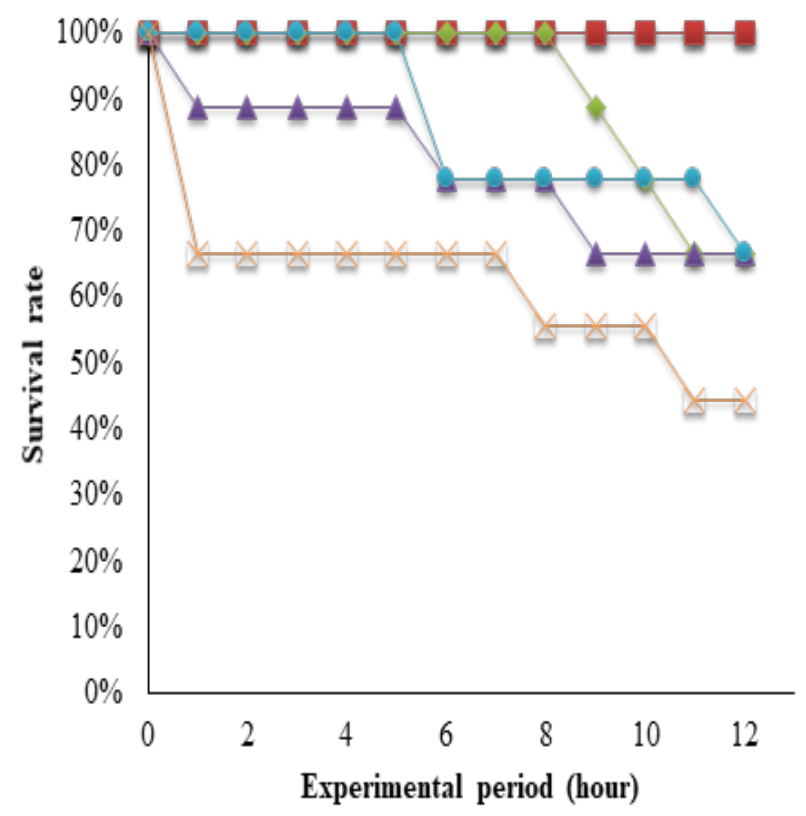

Figure 4 Survival rate of the fish over 12-hour post-recovery period following freezing at different temperatures; $\longrightarrow$ - $45^{\prime}$ extract used; $-45^{\prime}$ control; $\longrightarrow 60^{\prime}$ extract used; $\longrightarrow$ 60' control; $\longrightarrow 75^{\prime}$ extract used; $\longrightarrow 75^{\prime}$ control.

ekstrak kayu manis sebagai anestesi dapat mencegah kematian pada ikan karena tingkat stres ikan akan terhambat. Hal ini didukung oleh penelitian Suwetja et al. (2016), yang menyatakan pembekuan yang semakin lama dapat meningkatkan kematian pada ikan karena adanya suhu rendah menyebabkan ikan menjadi stres. Pembekuan yang diberikan pada ikan dapat memengaruhi kondisi ikan selama $12 \mathrm{jam}$. Hal tersebut didukung oleh penelitian Nugraha et al. (2019) yang menyatakan bahwa ikan yang diberi suhu rendah akan membuat metabolisme ikan menurun yang menjadikan konsumsi oksigennya menurun sehingga dapat menyebabkan kematian.

\section{Penampakan Mata dan Insang}

Pengujian mata dan insang dilakukan dengan mikroskop digital user manual-(G600) secara kualitatif, baik pada mata ikan setelah pemberian pembekuan maupun setelah bugar. Mata ikan dilihat langsung pada bagian kornea. Insang diamati dengan mengeluarkan insang dari kepala ikan. Pengujian ini dilakukan untuk melihat pengaruh ekstrak kayu manis dan perbedaan waktu pembekuan terhadap kenampakan mata dan insang ikan mas.

\section{Mata ikan mas}

Pengamatan mata ikan merupakan salah satu cara yang cukup mudah dilakukan untuk melihat kondisi ikan terutama pada tingkat kesegaran ikan (Pianusa et al. 2015). Kondisi mata ikan diamati pada bentuk mata dan warnanya. Kondisi mata ikan mas setelah diberi pembekuan dengan pemingsanan dan tanpa pemingsanan dapat dilihat pada Table 1.

Table 1 menunjukkan adanya perbedaan pada mata ikan yang menggunakan pemingsanan dan tanpa pemingsanan. Mata ikan yang dipingsankan menggunakan pemingsanan ekstrak kayu manis maupun tanpa pemingsanan sebelum dibugarkan memiliki warna mata yang keruh sedangkan ikan yang telah bugar memiliki warna yang lebih jernih. Ikan mas semakin lama diberi pembekuan membuat mata ikan terbentuk kristal es. Mata ikan pada kondisi segar memiliki bentuk mata yang cembung dan mempunyai warna yang jernih.

Ikan baik yang dipingsankan maupun tidak dipingsankan setelah dibugarkan kornea mata tampak jernih dan kondisi mata ikan pada seluruh perlakuan memiliki bentuk mata yang cembung. Kondisi mata ikan yang jernih dengan bentuk mata ikan yang cembung tersebut menandakan bahwa 
Table 1 The fish eye condition during freezing and after recovery

\begin{tabular}{l} 
Freezing \\
time $\left({ }^{\circ} \mathrm{C}\right)$ \\
\hline $45(\mathrm{~A} 1)$
\end{tabular}

Note: $\mathrm{A} 1=$ with cinnamon extract, $\mathrm{A} 2=$ without cinnamon extract (control)

kondisi ikan masih segar (Litaay et al. 2017). Meiriza et al. (2016) menyatakan bahwa ikan segar memiliki betuk mata yang menonjol, cerah dan kornea jernih. Kristal es yang terbentuk pada mata ikan disebabkan karena pada mata ikan terdapat air bebas yang saat suhu tubuh ikan berada di suhu $-10{ }^{\circ} \mathrm{C}$ atau lebih rendah akan berubah menjadi kristal es (KKP 2020). Waktu pembekuan yang semakin meningkat membuat mata ikan menjadi semakin berwarna putih keruh, karena kombinasi suhu rendah dan waktu diduga akan dapat membuat indeks bias juga semakin meningkat. Indeks bias yang semakin meningkat disebabkan oleh kerapatan medium yang dilewati. Zat cair yang terdapat pada mata ikan kerapatannya akan semakin meningkat seiring dengan lama waktu pembekuan yang diberikan membuat indeks biasnya meningkat (Zamroni 2013).

\section{Insang ikan mas}

Bagian organ ikan yang paling rentan dan sebagai indikator terhadap perubahan kondisi lingkungan salah satunya yaitu insang. Pengamatan insang ikan merupakan metode yang cukup valid untuk mengetahui ada atau tidaknya pengaruh waktu pembekuan yang berbeda terhadap kondisi insang ikan (Georgieva et al. 2014). Insang ikan sendiri berupa respirasi yang paling utama untuk melakukan difusi yang terdapat di dalam darah dan air seperti gas-gas. Struktur dan fungsi ikan akan terpengaruh sangat besar apabila terjadi perubahan pada lingkungan ikan baik yang terjadi secara langsung ataupun terjadi tidak secara langsung (Veronica et al. 2017). Kondisi insang ikan mas setelah diberi pembekuan yang berbeda dengan pemingsanan dan tanpa pemingsanan dapat dilihat pada Table 2. 
Table 2 The fish gill conditions

Freezing
Fime $\left({ }^{\circ} \mathrm{C}\right)$
Fresh, red gill with little blood clot
and mucus and visible of cinnamon extract.

Note: $\mathrm{A} 1=$ with cinnamon extract, $\mathrm{A} 2=$ without cinnamon extract (control)

Table 2 menunjukkan adanya perbedaan hasil di setiap lama waktu pemberian pembekuan $-13^{\circ} \mathrm{C}$ yang berbeda. Insang hasil pembekuan 45 menit memperlihatkan kondisi yang baik, sedangkan pada pembekuan 60 dan 75 menit terlihat bahwa insang mulai mengalami kerusakan terutama pada bagian filamen. Pembekuan 75 menit terdapat kerusakan yang berat pada filamen insang yaitu terlihat adanya jarak cukup besar antar filamen dan terjadinya pendarahan pada insang ikan. Fathihatunnisa (2019) menjelaskan dalam penelitiannya bahwa ikan yang tidak diberi pembekuan $-13{ }^{\circ} \mathrm{C}$ tidak akan mengalami kerusakan pada bagian filamennya, sedangkan ikan yang diberi pembekuan dapat menyebabkan kerusakan pada filamen. Filamen sendiri terbagi dua menjadi lamela sekunder dan lamela primer. Filamen yang mengalami kerusakan menyebakan terhambatnya air ataupun oksigen yang mengalir disebabkan oleh lamela sekundernya memiliki jarak yang sedikit antar lamela. Pemberian lama waktu pembekuan yang berbeda memengaruhi kondisi insang. Pembekuan juga dapat membuat kesegaran ikan tetap terjaga dan insang terlihat masih berwarna merah segar. Ikan yang masih segar dapat dilihat dari warna dan lendirnya, jika warnanya tidak berubah dan lendirnya sedikit maka ikan tersebut diduga kualitasnya masih segar (Litaay 2017).

\section{Kadar Glukosa Darah Ikan Mas dengan Ekstrak Kayu Manis dan Tanpa Ekstrak Kayu Manis}

Pengukuran kadar glukosa darah dilakukan dengan menggunakan alat uji GlucoDR AGM-2100. Darah ikan mas yang diuji diambil dari bagian pangkal 
Table 3 Glucose levels of the carp

\begin{tabular}{|c|c|c|c|c|}
\hline \multirow{2}{*}{$\begin{array}{l}\text { Freezing } \\
\text { time } \\
\text { (minutes) }\end{array}$} & \multicolumn{2}{|c|}{ With cinnamon extract } & \multicolumn{2}{|c|}{ Without cinnamon extract } \\
\hline & re & After & re & After \\
\hline 45 & $87.17 \pm 27.57$ & $134.67 \pm 39.43$ & $49.33 \pm 8.87$ & $143.33 \pm 37.81$ \\
\hline 60 & $111.50 \pm 22.29$ & $137.33 \pm 22.54$ & $64.50 \pm 2.78$ & $152.17 \pm 15.51$ \\
\hline 75 & $134.33 \pm 24.46$ & $151.33 \pm 38.89$ & $55.00 \pm 26.13$ & $160.50 \pm 38.25$ \\
\hline
\end{tabular}

ekor ikan menggunakan semprit (syringe) (Suwandi et al. 2013). Glukosa darah ikan diukur untuk mengetahui tingkat stres yang terjadi pada ikan. Kadar glukosa darah ikan yang meningkat dapat terjadi karena adanya efek sekunder dari stres serta memiliki pengaruh terhadap kesehatan ikan (Subiyono et al. 2016). Nilai kadar glukosa darah ikan mas dapat dilihat pada Table 3.

Table 3 memiliki nilai yang berbedabeda pada setiap perlakuannya. Nilai terbesar glukosa darah ikan yang didapat pada perlakuan dengan pemingsanan setelah diberikan pembekuan 75 menit, yaitu $151,33 \pm 38,89 \mathrm{mg} / \mathrm{dL}$ sedangkan yang terendah pada pembekuan 45 menit, yakni $134,33 \pm 24,46 \mathrm{mg} / \mathrm{dL}$. Kadar glukosa darah ikan yang terendah pada perlakuan tanpa pemingsanan yang sudah diberi pembekuan mendapatkan nilai sebesar 49,33 $\pm 8,87$ pada pembekuan 45 menit, sedangkan nilai glukosa darah yang tertinggi terdapat pada pembekuan 75 menit sebesar 160,50 $\pm 38,25$. Hasil yang didapat menunjukkan bahwa ikan yang dipingsankan terlebih dahulu sebelum dibekukan dapat menghambat peningkatan stres ikan. Hastuti et al. (2018) menyatakan bahwa kadar glukosa darah ikan yang normal berada di kisaran antara 41 sampai $150 \mathrm{mg} /$ dL. Hal ini menunjukan bahwa ikan tanpa pemingsanan setelah dibekukan selama 60 dan 75 menit mengalami stres.

Hasil tersebut menujukkan bahwa nilai glukosa darah yang didapatkan terlihat mengalami kenaikan pada perlakukan pemingsanan dengan anestesi dan kontrol. Peningkatan kadar glukosa darah tertinggi terjadi pada perlakuan kontrol. Peningkatan kadar glukosa darah menandakan ikan mengalamistresselamapemberian pembekuan sehingga ikan dengan kadar glukosa darah tinggi maka tingkatan stres yang dialami oleh ikan akan semakin tingggi. Hal tersebut sesuai dengan pernyataan Midihatama et al. (2018) bahwa ikan dengan tingkat stres yang tinggi menyebabkan kadar glukosa darah ikan yang dihasilkan akan semakin tinggi. Kadar glukosa darah yang tinggi disebabkan oleh ikan yang mengalami stres dan membutuhkan banyak energi dan membuat glukokortikoid menjadi meningkat. Syawal et al. (2012) menyatakan ikan dalam kondisi stres memerlukan banyak energi untuk beradaptasi dengan kondisi suhu yang ada dalam menjaga dirinya untuk tetap hidup yang berakibat glukosa akan bergerak ke dalam darah yang menyebabkan terjadinya peningkatan kadar glukosa darah. Ikan dengan perlakuan kontrol setelah diberikan pembekuan memiliki kadar glukosa darah yang lebih tinggi dari ikan dengan perlakuan pemingsanan. Hal ini sesuai dengan pernyataan Oktaviani (2016) bahwa perlakuan pemingsanan dengan anestesi mampu menghambat peningkatan kadar glukosa darah dengan menghambat peningkatan stres ikan.

\section{KESIMPULAN}

Pemberian ekstrak kayu manis dan kejutan suhu yang beku yang berbeda memberi pengaruh terhadap nilai laju sintasan ikan mas. Ikan mas yang diberi ekstrak kayu manis dan pembekuan menghasilkan nilai laju sintasan yang lebih tinggi dibandingkan ikan yang dipingsankan hanya menggunakan pembekuan. Namun perlu diperhatikan bahwa waktu pembekuan yang terlalu lama dapat membuat kerusakan fisik pada ikan yang teramati pada organ insang dan mata.

\section{DAFTAR PUSTAKA}

Aini M, Ali M, Putri B. 2014. Penerapan teknik imotilisasi benih ikan nila (Oreochromis niloticus) menggunakan ekstrak daun 
bandotan (Ageratum conyzoides) pada transportasi basah. Jurnal Rekayasa dan Teknologi Budidaya Perairan. 2(2): 217226.

Anto, Rato R. 2018. Pengaruh penambahan bubuk kayu manis (Cinnamomum burmannii) terhadap sifat kimia dan total mikroba pada nugget ayam. Jurnal Agropolitan. 5(1): 1-11.

Arlanda R, Tarsim, Utomo DSC. 2018. Pengaruh pemberian ekstrak tembakau (Nicotiana tobacum) sebagai bahan anestesi terhadap kondisi hematologi ikan nila (Oreochromis niloticus). Jurnal Sains Teknologi Akuakultur. 2(2): 32-40.

Arsyad M, DamayanthiW, Gemaputri AA. 2014. Pengaruh pemberian suhu $8{ }^{\circ} \mathrm{C}$ terhadap lama waktu pingsan ikan mas (Cyprinus carpio), ikan patin (Pangasius sp.), ikan lele (Clarias sp.), dan ikan gurame (Osphronemus guramy). Jurnal Ilmiah Inovasi. 14(2): 110-116.

Djarot P, Moerfiah, Ambarwati D. 2019. Lilin aromatik minyak atsiri kulit batang kayu manis (Cinnamomum burmannii) sebagai repelen lalat rumah (Musca domestica). Jurnal Ilmiah Ilmu Dasar dan Lingkungan Hidup. 19(2): 55-64.

Fathihatunnisa R. 2019. Perubahan Struktur Histologi Insang dan Mortalitas Ikan Mas (Cyprinus carpio) Akibat Pembekuan dan Pemingsanan Dengan Minyak Cengkeh. [Skripsi]. Bogor (ID) : Institut Pertanian Bogor.

Georgieva E, Velcheva I, Yancheva V, Stoyanova S. 2014. Trace metal effects on gill epithelium of Common Carp, Cyprinus carpio L. (Cyprinidae). Acta Zoologica Bulgarica. 66(2): 277-282.

[KKP] Kementrian Kelautan dan Perikanan. 2020. Laporan Kinerja Tahun 2019. Ditektorat Jendral Perikanan Budidaya. [Internet]. www.kkp.go.id

[KKP] Kementrian Kelautan dan Perikanan. 2020. Teknologi Baru Pembekuan Produk Perikanan. Badan Riset dan Sumber Daya Manusia Kelautan dan Perikanan. [Internet]. www.kkp.go.id

Khalil M, Yuskarina, Hartami P. 2013. Efektifitas dosis minyak pala untuk pemingsanan ikan nila (Oreochromis niloticus) selama transportasi. Jurnal Agrium. 10(2): 61-68

Litaay C, Wisudo SH, Haluan J, Harianto B. 2017. Pengaruh perbedaan metode pendinginan dan waktu penyimpanan terhadap mutu organoleptik ikan cakalang segar. Jurnal Ilmu dan Teknologi Kelautan Tropis. 9(2): 717-726.

Maraja MK, Salindeho N,Pongoh J. 2017. Penanganan ikan nila (Oreochromis niloticus) hidup dengan menggunakan es sebagai pengawet. Jurnal Media Teknologi Hasil Perikanan. 5(3): 174-179.

Maryani, Efendi E, Utom DSC. 2018. Efektifitas ekstrak bunga kenanga (Cananga odorata) sebagai bahan anestesi pada transportasi benih nila merah (Oreochromis sp.) tanpa media air. Indonesian Journal of Fisheries Science and Technology. 14(1): 8-15.

Midihatama A, Subandiyono, Haditomo AHC. 2018. Pengaruh eugenol terhadap kadar glukosa darah dan kelulushidupan benih ikan gurami (Osphronemus gouramy, Lac.) selama dan setelah periode transportasi sistem tertutup. Jurnal Sains Akuakultur Tropis. 2(2): 12-17

Munandar A, Indaryanto FR, Prestisia HN, Muhdani N. 2017. Potensi ekstrak daun picung (Pangium edule) sebagai bahan pemingsanan ikan nila (Oreochromis niloticus). Jurnal Teknologi Hasil Perikanan. 6(2): 107-114.

Nugraha S. 2019. Pengaruh Pemingsanan dan Pembekuan terhadap Mortalitas Ikan Mas (Cyprinus carpio). [Skripsi]. Bogor (ID) : Institut Pertanian Bogor.

Nur'aini M. 2016. Anestesi Ikan Mas (Cyprinus carpio) dengan Ekstrak Daun Sirih Hijau (Piper betle) pada Simulasi Transportasi. [Skripsi]. Bogor (ID) : Institut Pertanian Bogor.

Oktaviani IK. 2012. Pemanfaatan Daun Sirih (Piper betle) Sebagai Bahan Anestesi pada Proses Transportasi Ikan Nila (Oreochromis niloticus). [Skripsi]. Bogor (ID): Institut Pertanian Bogor.

Pianusa Af, Sanger G, Wonggo D. 2015. Kajian perubahan mutu kesegaran ikan tongkol (Euthynnus affinis) yang direndam dalam ekstrak rumput laut (Eucheuma spinosum) dan ekstrak buah bakau 
(Sonneratia alba). Jurnal Media Teknologi Hasil Perikanan. 3(2): 66-74.

Prasetyaningrum, Utami R, Anandito RBK. 2012. Aktivitas antioksidan, total venol, dan antibakteri minyak atsiri dan oleoresin kayu manis (Cinnamomum burmannii). Jurnal Teknosains Pangan. 1(1): 24-31.

Pratisari D. 2010. Transportasi Ikan Nila (Oreochromis niloticus) Hidup Sistem Kering dengan Menggunakan Pembiusan Suhu Rendah Secara Langsung. [Skripsi]. Bogor (ID) : Institut Pertanian Bogor

Primadona R, Lestari S, Baehaki A. 2017. Pengaruh pemberian kuat arus listrik terhadap tingkat kelulusan hidup pada transportasi kering benih ikan lele (Clarias sp.). Jurnal Teknologi Hasil Perikanan. 6(2): 145-152.

Puspita A. 2014. Pengaruh Konsentrasi Ekstrak Kayu Manis (Cinnamomum burmanii) dalam Menurunkan Pertumbuhan Streptococcus mutans Secara In Vitro. [Skripsi]. Surakarta (ID) : Universitas Muhammadiyah Surakarta.

Rahmahidayati I, Agustini TW, Nur M. 2014. Pengaruh penambahan ozon selama penyimpanan dingin terhadap kadar lemak bebas ikan nila merah (Oreochromis niloticus). Jurnal Pengolahan dan Bioteknologi Hasil Perikanan. 3(3): 16-22.

Roohi Z, Imanpoor MR. 2015. The efficacy of the oils of spearmint and methyl salicylate as new anesthetics and their effect on glucose levels in common carp (Cyprinus carpio L 1758) juveniles. Aquaculture. 437: 327-332.

Sari VD, Ningsih DS, Soraya NE. 2016. Pengaruh konsentrasi ekstrak kayu manis (Cinnamomum burmanii) terhadap kekasaran permukaan resin akrilik heat cured. Journal of Syiah Kuala Dentistry Society. 1(2): 130-136.

Septiana S. 2018. Ekstrak Kulit Kayu Manis (Cinnamomum sp.) Sebagai Anestesi Alami pada Simulasi Transportasi Ikan Mujair (Oreochromis mossambicus). [Skripsi]. Bogor (ID) : Institut Pertanian Bogor.

Subiyono, Martsiningsih MA, Gabrela D. 2016. Gambaran kadar glukosa darah metode GOD-PAP (Glucose OxsidasePeroxidase Aminoantypirin) sampel serum dan plasma EDTA (Ethylen Diamin Terta Acetat). Jurnal Teknologi Laboratorium. 5(1): 45-48.

Suwandi R, Nugraha R, Zulfamy KE. 2013. Aplikasi ekstrak daun jambu Psidium guajava var. pomifera pada proses transportasi ikan nila (Oreochromis niloticus). Jurnal Pengolahan Hasil Perikanan Indonesia. 16(1): 69-78.

Suwandi R, Nugraha S, Fathihatunnisa R, Jacoeb AM, Suptijah P. 2020. Effect of stunning and freezing on carp (Cyprinus carpio L) Survival rate. The Electrochemical Society. 414: 1-10.

Suwetja IK, Metang F, Pade SW. 2016. Studi teknik penanganan ikan mas (Cyprinus caprio-1) hidup dalam wadah tanpa air. Journal Technology. 4(1): 37-41.

Syafar LA,Mahasri G, Rantam FA. 2017. Blood description, parasite infestation and survival rate of carp (Cyprinus caprio) which is exposed by spore protein Myxobolus koi on rearing pond as immunostimulan material. Jurnal Biosains Pascasarjana.19(2): 1-18.

Syawal H, Kusumorini N, Manalu W, Affandi R. 2012. Respon fisiologis dan hematologi ikan mas (Cyprinus carpio) pada suhu media pemeliharaan yang berbeda. Jurnal Iktiologi Indonesia. 12(1): 1-11.

Veronica V, Iskandar CD, Rahmi E. 2017. Histologi insang dan labirin ikan gurami (Osphronemus gouramy Lac.). Jurnal Ilmiah Mahasiswa Veteriner. 2(1): 23-29.

Yanto H. 2009. Penggunaan MS-222 dan larutan garam pada transportasi ikan jelawat (Leptobarbus hoevenii Blkr.) ukuran sejari. Junal Ilmu-Ilmu Perairan dan Perikanan Indonesia. 16(1): 47-54.

Yustiati A, Pribadi SS, Rizal A, Lili W. 2017. Pengaruh kepadatan pada pengangkutan dengan suhu rendah terhadap kadar glukosa dan darah kelulusan hidup ikan nila (Oreochromis niloticus). Jurnal Akuatika Indonesia. 2(2): 137-145.

Zamroni A. 2013. Pengukuran indeks bias zat cair melalui metode pembiasan menggunakan plan paralel. Jurnal Fisika. 3(2): 108-111. 